\title{
Risk Factors for Severe Malnutrition in Under Five Children in Medan City
}

\author{
Erna Mutiara ${ }^{1}$, Rasmaliah $^{2}$ \\ ${ }^{1}$ Department of Population and Biostatistics, University of Sumatera Utara, Indonesia \\ erna3@usu.ac.id \\ ${ }^{2}$ Department of Epidemiology, University of Sumatera Utara, Indonesia \\ rasmaliah59@gmail.com
}

\begin{abstract}
Malnutrition in children under five years remains a serious public health problem. Medan city as the capital of the province of North Sumatera has the highest case of severe malnutrition compared to 32 districts/cities. Whereas the Medan City Health Office has made efforts maximally to reduce the number of severe malnourished. This study aimed to determine factors influenced the incidence of malnutrition in the Medan City by using unmatched case-control design. The sample consisted of 101 cases of children under five suffering from malnutrition recorded in Medan City Health Office during the month of May 2013 and 101 children under five did not suffer from severe malnutrition who lived closed to the cases. Malnutrition was determined by using the indicator weight-for height below -3 deviation standard of the WHO-NCHS. Data were collected by interviewing children under five's mothers directly and analyzed using multiple logistic regression. The result showed the factors that play a role together in the incidence of malnutrition in children under five in City of Medan were food intake $(\mathrm{OR}=\mathbf{2 . 5 1}, 95 \%$ CI 1.39 - 4.55), caring pattern $(\mathrm{OR}=1.89,95 \% \mathrm{CI}=1.06-3.39)$ and health services $(\mathrm{OR}=$ $1.87,95 \%$ CI 1.03 - 3.40). It was expected that mothers should pay attention and provide food with varied menu that children's nutrition needs fulfilled and improve caring patern.
\end{abstract}

Keywords - Malnutrition, under five children, food intake, caring pattern, Medan

\section{INTRODUCTION}

Malnutrition in children under five years old remains a serious public health problem that needs attention, especially malnutrition in developing countries. Malnutrition due to micronutrient deficiencies in children under five years adversely affect the health, motor development and growth of children under five [1]. Malnutrition among children is also associated with decreased function in adult life, decrease work capacity and productivity of the economy [2], [3].

In 2011 the five countries who have children under five years old who suffer stunting were India (61.7 million), Nigeria (11 million), Pakistan (9.6 million), China (8 million) and Indonesia (7.5 million) [4]. The prevalence of stunting in children under five have been found in Africa (36\% in 2011) and Asia (25\% in 2011). Although the prevalence of stunting and malnutrition showed a decline, but there has been no significant progress and millions of children remain at high risk [5].

In Indonesia, data from Basic Health Research (Riset Kesehatan Dasar $=$ Riskesdas) 2010 showed that the proportion of children under five based on weight/age (W/A) nutritional status, there were $17.9 \%$, underweight children comprising of $13.0 \%$, children with less nutrition status and $4.9 \%$ were severe malnutrition, $5.8 \%$ children with better nutritional status. Compared to the year 2007, a decline in under five malnutrition in 2010 from $18.4 \%$ to $17.9 \%$ [6]. Based on prevalence by province, the prevalence of underweight children was lowest achieved by North Sulawesi (10.6\%), Bali $(10.9 \%)$ and Jakarta $(11.3 \%)$. The provinces with the highest prevalence occured in Nusa Tenggara Barat $(30.5 \%)$, East Nusa Tenggara (29.4\%) and West Kalimantan (29.2\%). The MDG target achieved by 2015 for this indicator was $15.5 \%$. North Sumatera province is the province with high prevalence of infants with malnutrition (W/A) by $7.8 \%$ higher than the national rate of $4.9 \%[6]$.

North Sumatera Provincial Health Office recorded during the year 2012 there were 746 cases of malnutrition occured in some areas of North Sumatera. Of that number, mostly occured in the city of Medan (143 cases) [7]. Based on the latest data in 2013, Medan City Health Office recorded malnourished children in Medan were 110 and 1,417 undernourished children [8].

Medan City Health Office has sought to maximally reduce the number of malnourished or 
undernourished, by implementing a proactive system that visit families who have children with severe malnutrition directly. Technically, Nutritional Rehabilitation Centres (Pusat Pemulihan Gizi = PPG) that exist in the health centers are always dealing with cases of malnutrition in particularly.

Nutritional problems mostly is caused by two factors: the direct factors and indirect factors. Factors directly affecting the nutritional status area food intake (energy and protein) and illness. While the indirect factor among others is the level of knowledge, education level, income level, parenting, social, cultural, food security, health services and environmental factors [9].

This study aims to determine the risk factors effect the incidence of malnutrition among children under five in the city of Medan.

\section{METHODS}

This study is an unmatched case-control study. The study population was children with severe malnutrition recorded in Medan City Health Office during may 2013 and healthy children who are not malnourished who lived in the working area of Medan City health centers. Because this study uses the case-control design so study sample consisted of children under five are malnourished as a case sample and children who are not malnourished as a control sample.

Cases were children under five malnourished with body mass index for age $(\mathrm{W} / \mathrm{H})<-3 \mathrm{SD}$ WHONCHS (2005) and it has been diagnosed that the children under five suffer from malnutrition by doctors, who lived in the working area of Medan city health centers, recorded in Medan City Health Office during May 2013 and verified with data recorded by Tenaga Pelaksana Gizi (= TPG) in each clinic. The controls were not severely malnourished under five children who live near the location of malnourished children in the working area of Medan City health centers.

After calculation, the sample size required for cases and controls were 148 under five children, consisting of 74 cases of malnutrition children and 74 children who are not malnourished. However, because in the field it was found 101 cases of severe malnutrition under five children who qualified as samples, then all of 101 cases of severe malnutrition under five children and 101 under five children not malnourished were analyzed.

The variables that were collected for analysis consisted of the characteristics of under five children (food intake, health status), mother's characteristics (mother's occupation, level of knowledge, level of education), economic status, parenting, food security, health services, environmental conditions.

The data collection was done by direct interview using a questionnaire that had been tested. The stages of data analysis included univariate, bivariate and multivariate by using multiple logistic regression. Significance variables were assessed using a significance level of $5 \%$.

\section{RESULT}

Characteristics of cases and controls: The average age of cases and controls, respectively $28.8 \pm 14.1$ months and $22.2 \pm 14.2$ months. When it was grouped over 1-11 months, 12-35 months and 36-59 months, as many as 7 children (6.9\%) aged 1-11 months, 61 children $(60.4 \%)$ aged 12-35 months and 33 children $(32.7 \%)$ in the case group, while the control group each totaled 27 infants $(26.7 \%)$, 51 children $(50.5 \%)$ and 23 children $(22.8 \%)$ respectively. There were $54(53.5 \%)$ male children in the case group and 47 male children $(46.5 \%)$ in the control group. Higher education level (high school and above) on mothers in the case group were $53(52.5 \%)$, it was lower than the control group of 68 mothers $(67.3 \%)$ and higher education on the father in the case group as many as 47 $(46.5 \%)$, it was lower than the control group of 66 $(65.3 \%)$. The majority of mothers, $82(81.2 \%)$ in case group and $84(83.2 \%)$ in the control group were housewife. Father's main occupation in the cases and controls mostly work in the informal sector (such as laborers, rickshaw drivers, driver, etc.) were $70(69.3 \%)$ and $67(66.3 \%)$ respectively. Economic status are measured by quintile household expenditure per month, in the case group most families came from low socioeconomic status $(76.2 \%)$ while in the control group most families came from low socioeconomic status (66.3\%). Families with a number of household members aged 1-59 months more than two person mostly 
found in the case group as many as 10 children (9.9\%) than control group as many as 6 children $(5.9 \%)$. (Table 1)

TABLE I

DISTRIBUTION CASES AND CONTROL

\begin{tabular}{|c|c|c|c|c|}
\hline \multirow[t]{2}{*}{ Variable } & \multicolumn{2}{|c|}{ Cases } & \multicolumn{2}{|c|}{ Control } \\
\hline & $\mathbf{n}$ & $\%$ & $\mathbf{n}$ & $\%$ \\
\hline \multicolumn{5}{|l|}{ Age (months) } \\
\hline $1-11$ & 07 & 6,9 & 27 & 26,7 \\
\hline $12-35$ & 61 & 60,4 & 51 & 50,5 \\
\hline $36-59$ & 33 & 32,7 & 23 & 22,8 \\
\hline \multicolumn{5}{|l|}{ Sex } \\
\hline Male & 54 & 53,5 & 47 & 46,5 \\
\hline Female & 47 & 46,5 & 54 & 53,5 \\
\hline \multicolumn{5}{|l|}{ Mother's education } \\
\hline $\begin{array}{l}\text { Low (Junior high } \\
\text { school below) }\end{array}$ & 48 & 47,5 & 33 & 32,7 \\
\hline $\begin{array}{l}\text { High (Senior high } \\
\text { school above) }\end{array}$ & 53 & 52,5 & 68 & 67,3 \\
\hline \multicolumn{5}{|l|}{ Father's education } \\
\hline $\begin{array}{l}\text { Low (Junior high } \\
\text { school below) }\end{array}$ & 54 & 53,5 & 35 & 34,7 \\
\hline $\begin{array}{l}\text { High (Senior high } \\
\text { school above) }\end{array}$ & 47 & 46,5 & 66 & 65,3 \\
\hline \multicolumn{5}{|l|}{ Mother's occupation } \\
\hline Working & 19 & 18,8 & 17 & 16,8 \\
\hline $\begin{array}{l}\text { Not working (house } \\
\text { wife) }\end{array}$ & 82 & 81,2 & 84 & 83,2 \\
\hline \multicolumn{5}{|l|}{ Father's occupation } \\
\hline Not working & 07 & 6,9 & 01 & 1,0 \\
\hline Informal Job & 70 & 69,3 & 67 & 66,3 \\
\hline Formal Job & 24 & 23,8 & 33 & 32,7 \\
\hline \multicolumn{5}{|l|}{ Social Economy } \\
\hline Low (Quintile 1 - 3) & 77 & 76,2 & 67 & 66,3 \\
\hline $\begin{array}{l}\text { High (Quintile } 4 \text { and } \\
\text { 5) }\end{array}$ & 24 & 23,8 & 34 & 33,7 \\
\hline \multicolumn{5}{|l|}{$\begin{array}{l}\text { Number of house } \\
\text { hold member } 1 \text { - } 59 \\
\text { months }\end{array}$} \\
\hline$>2$ person & 10 & 9,9 & 06 & 5,9 \\
\hline$\leq 2$ person & 91 & 90,1 & 95 & 94,1 \\
\hline
\end{tabular}

To determine the relationship between risk factors and the incidence of severe malnutrition it was analyzed by using chi-square test at the significance level of 5\% (95\% Confidence Interval). The results of the analysis were presented in Table 2.

In the group of malnutrition children, mostly have poor food intake $(65.3 \%)$. While in the control group, many children have sufficient food intake $(56.4 \%)$. The results showed there was no relationship between food intake with the incidence of malnutrition among children under five, where the risk of malnutrition in children under five with poor food intake approximately 2.44 times greater than the under five children with moderate food intake (95\% CI 1.38 to 4.31 ).

In Mata health center in the working area of Kendari, the risk of malnutrition in under five children with poor energy intake approximately 6.79 times greater than the children with moderate energy intake (95\% CI 1.99 to 23.36). While the risk of malnutrition in under five children whose protein intake was poor approximately 10.28 times greater than children whose protein intake is sufficient (95\% CI 2.78 to 38.25 ). ${ }^{11}$ Same with the research in the region of Sewon I health center Bantul showed there was no association between food intake and nutritional status using indicators weight/height where under five children with poor food intake (energy), have a chance to get abnormal nutritional status by 2.872 times greater than the children with moderate food intake (energy) (95\% $\mathrm{CI}=2.03$ to 4.07 ) [13].

Children with severe malnutrition as much as $65.3 \%$ had experienced illness in the last one week, higher than that of children under five in the control group (51.5\%). From the statistical test found a significant relationship between the health status and the incidence of malnutrition $(p<0.05)$. Risk of malnutrition in children under five with good health status was 1.78 times greater than children who are not in good health status (95\% CI 1.01 to 3.13). In East Padang District the magnitude of risk of malnutrition among under five children with poor health status was approximately 5.04 greater than children with moderate health status (95\% CI 2.00 to 12.74$)$ [12].

When it was viewed from the mother's occupation, both in the group of malnutrition children or the control group, most of her only as a housewife (respectively $81.2 \%$ and $83.2 \%$ ). There was no relationship between the mother's occupation with the incidence of malnourished under five children. There was no difference in the risk of malnutrition of children in mothers who work and those not working. It was shown from the value of OR of 1.15 (95\% CI 0.56 to 2.36). The results were consistent with research in Islamabad Pakistan who reported it was not found an association between mother's occupational and nutritional status among under five children [14], [15]. 
Statistical analysis showed there was no association between mother's knowledge with the incidence of malnutrition in under five children. The proportion of mothers in case group with poor knowledge was $52.5 \%$ higher than the proportion of mothers in control group (40.6\%). Although there were differences in the proportion of $11.9 \%$, but this difference was not statistically significant.

The difference this finding could be due to differences in determining the cut point score of knowledge or could have been due to differences in determining the children's age restrictions. In addition, from the result of cross tabulation between knowledge of mothers with food intake, in group of mothers with good knowledge there were $55.6 \%$ under five children received less food intake.

The proportion of mothers in the case group mostly had low education (junior high school and below) of $47.5 \%$ compared to the control group $(32.7 \%)$. There was a relationship between mother's education with the incidence of malnutrition with OR of 1.87 (95\% CI 1.06 to 3.30). This meant the risk of malnutrition of children in mothers with low education 1.87 times greater than mothers with high education. Although there were differences in the determination of the indicator status of malnutrition, some studies reported there were no association between mother's education and severe malnutrition [12], [16]-[20].

In this study, the economic status was measured by food and non-food expenditure each month. In term of socio-economic status, nearly all cases of malnutrition children were from families with low socioeconomic $(76.2 \%)$ while the control group had low socioeconomic status of $66.3 \%$. The analysis also showed there was no association between socio-economic status with the incidence of malnutrition. Low socio-economic may affect the fulfillment of foodstuffs especially nutritious food.

Of the 101 samples the majority of cases $(75 \%)$ had poor parenting. While most of the 101 control samples $(79.7 \%)$ had good parenting. Statistical test result in finding the value of $p=0.001$, it meant that there was a relationship between parenting with the incidence of malnutrition among under five children that the risk of occurrence of malnutrition in under five children with poor parenting 12.24 times compared to children with good parenting. Parenting greatly affect the growth and development of children as children got more attention in both the physical and emotional state will have better nutrition compared to their peers who lack of attention [21].

This study found there was no significant association between household food security with the incidence of malnutrition. In the case group the proportion of insecure food still in the mild category amounted to $46.5 \%$, while in the control group $40.6 \%$.

In contrast to the study in Banjarnegara Central Java, which drew the conclusion that the level of household food security had a positive and significant correlation with nutritional status using of Weight/Height indicator $(r=0.142 ; \mathrm{p}<0.01)$. This meant that the higher the level of household food security will be the higher the nutritional status of a child [22].

The proportion of under five children suffering from malnutrition was greater among mothers or care givers stated that health service was not good $(49.5 \%)$ than in the control group (36.6\%), although the results showed no association between health service and the incidence of malnutrition. These results were in contrast to studies in East Padang, and in Kebumen who reported there was relationship between the health service with the incidence of malnutrition of children. This was due to mothers/caregivers who stated good health service, $59.1 \%$ of under five children did not get enough food intake compared to mothers/caregivers who stated that health service was not good. ${ }^{12,23}$

Environmental factors that could affect the nutritional status was the fuel used for cooking which could be a gas/kerosene/charcoal/firewood fuel. In this study, the type of fuel that was considered good when using gas fuel. In the group of children malnutrition, the proportion of mothers using fuels other than gas as much as $37.6 \%$ higher than mothers in the control group (21.8\%). Air pollution generated can cause respiratory diseases. Children were exposed Acute Respiratory Infection (ARI) will tend to be difficult to eat. This will lead to weight loss children. Results showed the risk of malnutrition in children under five living in families that use kerosene/charcoal/firewood fuel was 2.17 
times greater than children who live in families that use gas fuels (95\% CI 1.16 to 4.03 ).

The proportion of malnutrition children living in families with smoking habit as much as $62.4 \%$ while the control group as much as $48.5 \%$. Risk of malnutrition in children under five living in families that have smoking habit by 1.76 times compared to children who live in families that do not have the habit of smoking (95\% CI 1.00 to 3.08).

TABLE II

CROSS TABUlation Risk FACTOR FOR SEVERE MALNUTRITION

\begin{tabular}{|c|c|c|c|c|c|c|c|c|}
\hline \multirow[t]{2}{*}{ Risk Factors } & \multicolumn{2}{|c|}{ Case } & \multicolumn{2}{|c|}{ Control } & \multirow[t]{2}{*}{$\chi^{2}$} & \multirow[t]{2}{*}{ OR } & \multirow[t]{2}{*}{$95 \%$ CI } & \multirow[t]{2}{*}{$\mathbf{P}$} \\
\hline & $\mathrm{n}$ & $\%$ & $\mathrm{n}$ & $\%$ & & & & \\
\hline \multicolumn{9}{|l|}{ Food Intake } \\
\hline Poor & 66 & 65,3 & 44 & 43,6 & 9,661 & 2,44 & $1,38-4,31$ & 0,002 \\
\hline Moderate & 35 & 34,7 & 57 & 56,4 & & & & \\
\hline \multicolumn{9}{|c|}{ Health Status' Children } \\
\hline Ill & 66 & 65,3 & 52 & 51,5 & 3,994 & 1,78 & $1,01-3,13$ & 0,046 \\
\hline Healthy & 35 & 34,7 & 49 & 48,5 & & & & \\
\hline \multicolumn{9}{|l|}{ Mother's occupation } \\
\hline Working & 19 & 18,8 & 17 & 16,8 & 0,135 & 1,15 & $0,56-2,36$ & 0,713 \\
\hline Not working & 82 & 81,2 & 84 & 83,2 & & & & \\
\hline \multicolumn{9}{|l|}{ Mother's knowledge } \\
\hline Poor & 53 & 52,5 & 41 & 40,6 & 2,865 & 1,62 & $0,93-2,82$ & 0,091 \\
\hline Good & 48 & 47,5 & 60 & 59,4 & & & & \\
\hline \multicolumn{9}{|l|}{ Mother's education } \\
\hline Low & 48 & 47,5 & 33 & 32,7 & 4,637 & 1,87 & $1,06-3,30$ & 0,031 \\
\hline High & 53 & 52,5 & 68 & 67,3 & & & & \\
\hline \multicolumn{9}{|l|}{ Economy Status } \\
\hline Low & 77 & 76,2 & 67 & 66,3 & 2,419 & 1,63 & $0,88-3,02$ & 0,120 \\
\hline High & 24 & 23,8 & 34 & 33,7 & & & & \\
\hline \multicolumn{9}{|l|}{ Parenting } \\
\hline Poor & 63 & 62,4 & 44 & 43,6 & 7,174 & 2,15 & $1,22-3,77$ & 0,007 \\
\hline Good & 38 & 37,6 & 57 & 56,4 & & & & \\
\hline \multicolumn{9}{|l|}{ Food insecurity } \\
\hline Severe & 8 & 7,9 & 4 & 4,0 & 5,815 & 3,15 & $0,86-11,54$ & 0,118 \\
\hline Moderate & 20 & 19,8 & 15 & 14,9 & & 2,10 & $0,92-4,82$ & \\
\hline Mild & 47 & 46,5 & 41 & 40,6 & & 1,81 & $0,95-3,45$ & \\
\hline Secure & 26 & 25,7 & 41 & 40,6 & & 1,00 & & \\
\hline \multicolumn{9}{|l|}{ Health service } \\
\hline Poor & 50 & 49,5 & 37 & 36,6 & 3,412 & 1,70 & $0,97-2,98$ & 0,065 \\
\hline Good & 51 & 50,5 & 64 & 63,4 & & & & \\
\hline \multicolumn{9}{|c|}{ Environmental condition } \\
\hline \multicolumn{9}{|c|}{ Type of roof } \\
\hline Poor & 5 & 5,0 & 3 & 3,0 & 0,521 & 1,70 & $0,40-7,32$ & 0,471 \\
\hline Good & 96 & 95,0 & 98 & 97,0 & & & & \\
\hline \multicolumn{9}{|l|}{ Type of wall } \\
\hline Poor & 46 & 45,5 & 34 & 33,7 & 2,980 & 1,65 & $0,93-2,91$ & 0,084 \\
\hline Good & 55 & 54,5 & 67 & 66,3 & & & & \\
\hline Type of floor & & & & & & & & \\
\hline Poor & 11 & 10,9 & 7 & 6,9 & 0,976 & 1,64 & $0,61-4,42$ & 0,323 \\
\hline Good & 90 & 89,1 & 94 & 93,1 & & & & \\
\hline Source of drinking wat & & & & & & & & \\
\hline Poor & 9 & 8,9 & 3 & 3,0 & 3,189 & 3,20 & $0,84-12,17$ & 0,074 \\
\hline Good & 92 & 91,1 & 98 & 97,0 & & & & \\
\hline Type of closet & & & & & & & & \\
\hline Poor & 8 & 7,9 & 5 & 5,0 & 0,740 & 1,65 & $0,52-5,23$ & 0,390 \\
\hline Good & 93 & 92,1 & 96 & 95,0 & & & & \\
\hline Fecal landfills & & & & & & & & \\
\hline Poor & 32 & 31,7 & 27 & 26,7 & 0,599 & 1,27 & $0,69-2,34$ & 0,439 \\
\hline Good & 69 & 68,3 & 74 & 73,3 & & & & \\
\hline Fuel & & & & & & & & \\
\hline
\end{tabular}




\begin{tabular}{|l|l|l|l|l|l|l|l|c|}
\hline Poor & 38 & 37,6 & 22 & 21,8 & 6,069 & 2,17 & $1,16-4,03$ & 0,014 \\
\hline Good & 63 & 62,4 & 79 & 78,2 & & & & \\
\hline Smoking habit & & & & & & & & \\
\hline Yes & 63 & 62,4 & 49 & 48,5 & 3,928 & 1,76 & $1,00-3,08$ & 0,047 \\
\hline No & 38 & 37,6 & 52 & 51,5 & & & & \\
\hline
\end{tabular}

To determine the factors that affect the incidence of malnutrition children it was used multiple logistic regression test with the prediction model. Variables that will be the candidate prediction model, selected from each of the risk factors in the cross tabulation analysis has a $p$-value $\leq 0.25$. The final results of predictive models can be seen in the following table.

TABLE III

FinAl MODEl FACTORS INFLUENCE SEVERE MALNUTRITION

\begin{tabular}{|l|c|c|c|c|c|}
\hline \multicolumn{1}{|c|}{ Variable } & $\begin{array}{c}\text { Coefficient } \\
\mathrm{B}\end{array}$ & Wald & $\mathrm{p}$ & OR & $95 \%$ CI \\
\hline Food Intake & 0,920 & 9,224 & 0,002 & 2,51 & $1,39-4,55$ \\
\hline $\begin{array}{l}\text { Caring } \\
\text { patern }\end{array}$ & 0,639 & 4,622 & 0,032 & 1,89 & $1,06-3,39$ \\
\hline $\begin{array}{l}\text { Health } \\
\text { service }\end{array}$ & 0,626 & 4,231 & 0,040 & 1,87 & $1,03-3,40$ \\
\hline Constant & $-1,110$ & 13,196 & 0,001 & 0,33 & \\
\hline
\end{tabular}

From the analysis it can be seen that the variable food intake had the highest coefficient $\mathrm{B}$, which meant that the food intake was the most variable large contribution to the incidence of malnourished under five children. This condition in accordance with the theory that the immediate cause of the problem is nutritional intake of food. Risk of malnutrition in children under five with poor food intake approximately 2.51 times greater than the children with moderate food intake (95\% CI 1.39 to 4.55) after controlled by variable parenting and health services.

\section{CONCLUSIONS}

Factors that play a role simultaneous in the incidence of malnourished under five children in Medan City is the food intake, the type of fuel used for cooking, and health services. The factor that most influenced the incidence of malnourished under five children in Medan City was the food intake where the risk of malnutrition in under five children with poor food intake approximately 2.5 times greater than children with moderate food intake.

Mothers should pay attention and increase the need for food containing the consumption of energy and protein and provide food with a diverse menu so that the nutritional needs of children fulfilled, improve parenting and specifically for health service, it is suggested to the government and the private sector in order to build health facilities should pay attention to the distance and ease of access to the public.

\section{REFERENCES}

[1] Crawley J. Reducing the burden of anemia in infants and young children in malaria-endemic countries of Africa: From evidence to action. Am. J. Trop. Med. Hyg, 2004; 71(Suppl 2): 25-34.

[2] Schroeder DG, Brown KH. Nutritional status as a predictor of child survival: summarizing the association and quantifying its global impact. Bull. World Health Organ., 1994;72: 569-579.

[3] Mendez MA, Adair LS. Severity and timing of stunting in the first two years of life affect performance on cognitive tests in late childhood. J. Nutr., 1999;129: 1555-1562.

[4] UNICEF. Improving Child Nutrition: The Achievable Imperative for Global Progress, New York; 2013.

[5] UNICEF, WHO dan the World Bank. Levels and Trends in Child Malnutrition: UNICEF-WHO-The World Bank Joint Child Malnutrition Estimates; 2012.

[6] Kementerian Kesehatan Republik Indonesia. Profil Kesehatan Indonesia Tahun 2011. Jakarta: Kementerian Kesehatan Republik Indonesia; 2012.

[7] Portal KBR.com. Medan Juara Kasus Gizi Buruk; 2013 [cited 2013 March 18]. Available from http://www.portalkbr.com/nusantara/ acehdansumatera/2481822_4264.html.

[8] starberita.com. Bahrumsyah: Dinkes Tak Punya Data Riil Soal Gizi Buruk; 2013 [cited 2013 March 18]. Available from http://www.starberita.com/ index.php? option=com content\&view =article\&id=92729:bahrumsyah-dinkes-tak-punya-data-riil-soal-giziuruk\&catid=37 :medan\&Itemid $=457$.

[9] UNICEF. The State of the World's Children, Oxford University Press, New York; 1998.

[10] Lemeshow S, Hosmer Jr DW, Klar J, Lwanga SK, Editors. Adequacy of Sample Size in Health Studies. John Wiley \& Sons, Chichester.

[11] Nurlila RU. Faktor Penyebab Gizi Buruk pada Anak Balita di Wilayah Kerja Puskesmas Mata Kota Kendari; 2010 [cited June 24 2013]. Available from http://psbldotnet. wordpress. com/2011/12/10-faktorpenyebab-gizi-buruk-pada-anak-balita-di-wilayah-kerja -puskesmasmata-kota-kendari-ratna-umi-nur lila.docx.

[12] Faiza R, Deni E, Syafianti. Faktor Risiko Kejadian Gizi Buruk pada Anak Balita (12-59 Bulan) di Wilayah Kerja Puskesmas Andalas Kecamatan Padang Timur, Media Gizi \& Keluarga. 2007;31(1):80-88.

[13] Purwaningrum S, Wardani Y. Hubungan Antara Asupan Makanan dan Status Kesadaran Gizi dengan Status Gizi Balita di Wilayah Kerja Puskesmas Sewon I, Bantul, KESMAS. 2012;6(3):190-202.

[14] Shaikh FA, Kamsrichan W, Vorakitphankatorn S. Factors Affecting Nutritional Status of Five Years Old Children in Islamabad Pakistan, Journal of Public Health and Development. 2007;5(3):75-85.

[15] Nurani N, Sitaresmi MN, Ismail Dj. Risk Factors for Malnutrition in Under-Five Children: One Year After the Yogyakarta Earthquake, Paediatrica Indonesiana. 2011;51(6):327-331.

[16] Siddiqi MNA, Haque MN, Goni MA. Malnutrition of Under-Five Children: Evidence from Bangladesh, Asian Journal of Medical Sciences. 2011;2:113-119.

[17] Santi DY, Utama SP, Putranto AMH. Hubungan Antara Kondisi Sosial Ekonomi dan Hygiene Sanitasi Lingkungan dengan Status Gizi Anak Usia 2-5 Tahun di Kecamatan Seginim Kabupaten Bengkulu Selatan Tahun 2012. NATURALIS. 2012;1(2):141-146. 
[18] Abuya BA, Ciera J, Kimane-Murage E. Effect of Mother's Education on Child's Nutritional Status in the Slums of Nairobi, BMC Pediatrics. 2012;12:80.

[19] Abubakar A, Uriyo J, Msuya SE, Swai M, Stray-Pederson, B. Prevalence and Risk Factors for Poor Nutritional Status among Children in the Kilimanjaro Region of Tanzania, International Journa of Environmental Research and Public Health. 2012;9: 3506-3518.

[20] Hasnain SF, Hashmi SK. Consanguinty among the Risk Factors for Underweight in Children Under Five: A Study for Rural Sindh, Journal of Ayub Medical Collegge Abbottabad. 2009;21(3):111-116.

[21] Soetjiningsih. Buku Ajar Tumbuh Kembang Remaja dan Permasalahannya, Sagung Seto, Jakarta; 2004

[22] Soblia, E, T, 2009. Tingkat Ketahanan Pangan Rumah Tangga, Kondisi Lingkungan, Morbiditas, dan Hubungannya dengan Status Gizi Anak Balita pada Rumah Tangga di Daerah Rawan Pangan Banjarnegara, Jawa Tengah, Skripsi, Fakultas Ekologi Manusia, Institut Pertanian Bogor.

[23] Hidayat Y, Asrin and Sumarni, 2011. Analysis of Factors Inluenced Severe Malnutrition among Under Five Children in Kebumen District in 2010, http://akbid.otyliahost.com/wp-ntent/uploads/2011/12/ analisis\%20faktor.pdf, accessed 26 Agustus 2013. 